\title{
Pus: the Rodney Dangerfield of immunology
}

\author{
David S Pisetsky*
}

The American comedian Rodney Dangerfield was famous for his catch phrase 'I don't get no respect', which he used to punctuate monologues throughout an illustrious career. The fulcrum of humor on topics such as drinking, sex and marriage, the phrase fit well the persona of Dangerfield. This was a man whose appearance disrespected respect. His eyes bulged, he was nervous and jittery and he constantly tugged at his collar and wiped sweat from his brow. It seemed that, no matter what Dangerfield did, respect would keep far from his way.

Biological fluids do not speak (or do stand-up) but, if they did, pus would be the Rodney Dangerfield of immunology, definitely complaining about its treatment. While arguably one of the most critical expressions of innate immunity - a veritable magic elixir to vanquish infection and decontaminate the most noxious debris pus per se does not appear to be the focus of many studies. Consider the following statistics. For the year 2010, Medline lists 259 citations with pus as a key word. In contrast, exudate had 412 citations and effusion had 1,525 . I could not find one reference ever published on the pus proteome.

Not only is pus uncommonly a research topic but investigators do not seem to want to identify themselves with this fluid. Who is the world's pus expert? I do not know anyone who has embraced this distinction. The situation is not surprising since pus is not the most pleasant material in the world. It is thick, slimy and gooey - indeed, downright yucky. The color is disgusting unless you like a vile mélange of yellow, green and brown. And the stuff often stinks. Even though it is readily accessible in the clinic and ward - an easily sampled bonanza for biomarker development and translational research - investigators turn their heads (and noses) away when pus is around.

Times may be changing, however, and pus may finally be attracting the attention and respect that it deserves. The impetus for such change has been the discovery of one of the most ingenious systems for host defense that the immune system deploys. This system has been

*Correspondence: dpiset@acpub.duke.edu

Duke University Medical Center 151G Durham VAMC Durham, NC 27705, USA termed NETs, an acronym that stands for neutrophil extracellular traps. In simplest form, NETs represent the DNA from a neutrophil that has been extruded into the extracellular space by a unique mechanism called NETosis. In NETosis, certain activating influences can trigger a cellular transformation in which the nuclear membrane breaks down, DNA mixes with cytoplasm and the whole assemblage is jettisoned from the cell, providing a key ingredient for pus and other exudates (Figure 1). Depleted of its DNA, the neutrophil cannot survive and NETosis is as much a form of cell death as cell activation, albeit specific for neutrophils [1-3].

While an expression of innate immune activation, NETs are unlike any other weapon in the arsenal of host defense since they represent a physical structure to ensnare and immobilize bacteria and other microorganisms in a mesh or net-like structure. Like a fly in a spider's web, the organisms are stuck and can be further attacked by the antibacterial proteins that stud the DNA [1-3]. Interestingly, histones have anti-bacterial activity, providing another example of a nuclear molecule doing double duty for the cell, fulfilling important functions in both the intracellular and extracellular space [4].

In addition to their function in the defense against infection, NETs may contribute to the pathogenesis of rheumatic disease. NETs are present at sites of tissue injury in vasculitis, promote thrombosis (an important concomitant of many connective tissue diseases) and represent an important source of DNA to form immune complexes and drive type I interferon production [5-9]. The role of extracellular DNA and RNA in immunopathogenesis is a booming field, leading to exploration of new biomarkers (that is, blood nucleome) as well as targets of therapy (for example, Toll-like receptor ligands). Certainly, it will be interesting to explore the effects on NETs formation of glucocorticoids whose effects on neutrophils have long been recognized but remain poorly understood.

Given the physical properties of pus, the existence of NETs should not have been unexpected. High molecular weight polymers like DNA confer viscosity and pus is very viscous. The obvious questions to be asked were 'Why is pus viscous?' and 'Is viscosity important to the activity of pus?' In a sense, some physicians appreciated the importance of viscosity long ago since they 


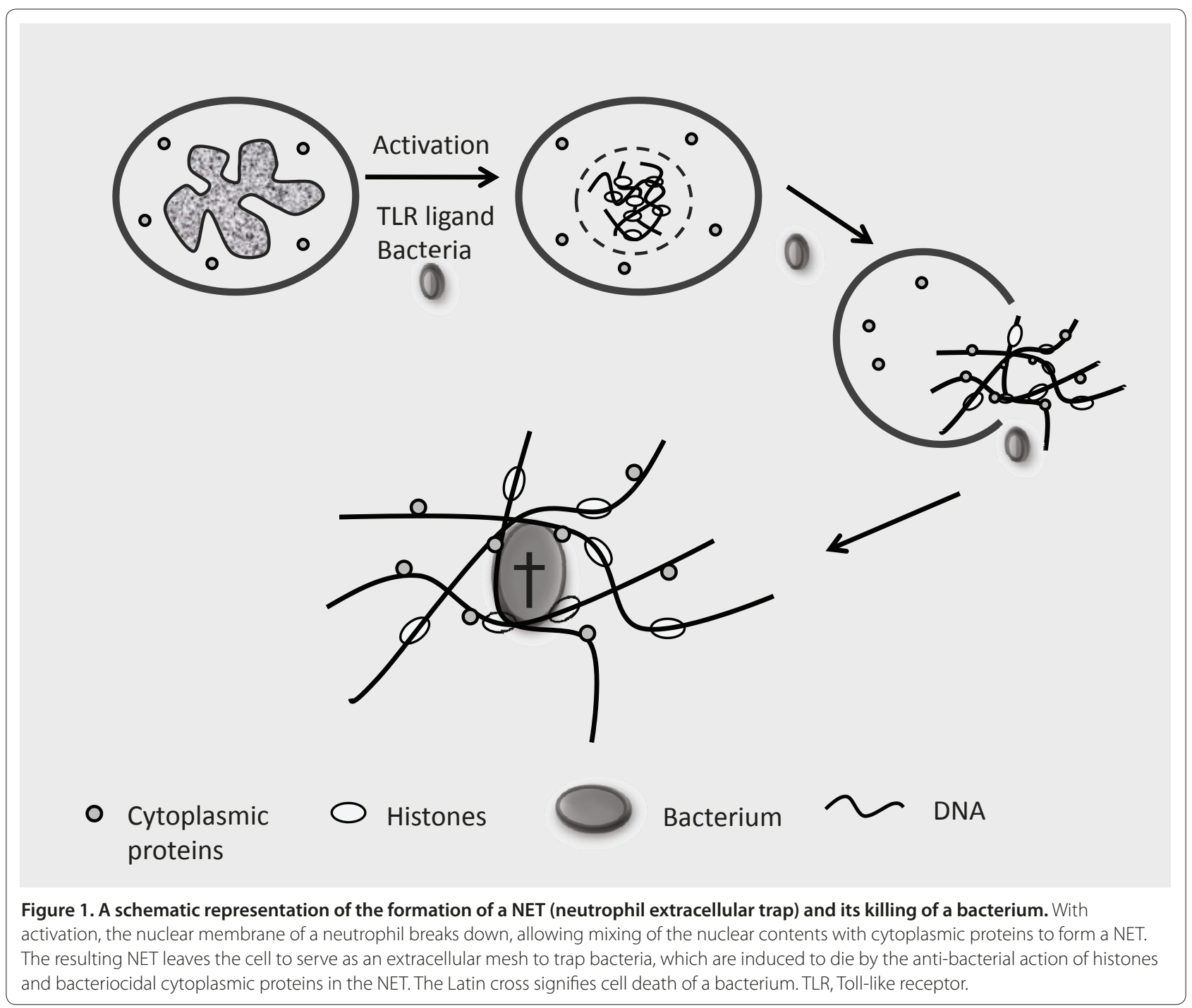

distinguished pus by its quality, with thick pus good and thin pus bad. With current understanding, it appears that good pus has NETs while bad pus lacks these structures, whether by inadequate production or excessive degradation.

While the biology of NETs will only grow in interest, it is remarkable that such fascinating biology was neglected until recently. If Rodney Dangerfield were an immunologist instead of a comedian, I know his take on the situation. With frustration and exasperation, he would have sputtered, 'I tell ya, pus don't get no respect.' And, he would have been right.

\section{Abbreviations}

NET, neutrophil extracellular trap.

Published: 26 October 2011

\section{References}

1. Brinkmann V, Reichard U, Goosmann C, Fauler B, Uhlemann Y, Weiss DS, Weinrauch Y, Zychlinsky A: Neutrophil extracellular traps kill bacteria. Science 2004, 303:1532-1535.
2. Brinkmann V, Zychlinsky A: Beneficial suicide: why neutrophils die to make NETS. Nat Rev Microbio/ 2007, 5:577-582.

3. Remijsen Q, Kuipers TW, Wirawan E, Lippens S, Vandenabeele P, Vanden Berghe T: Dying for a cause: NETosis, mechanisms behind an antimicrobial cell death modality. Cell Death Differ 2011, 4:581-588.

4. Wang Y, Griffiths WJ, Järnvall $H$, Agerberth B, Johansson J: Antibacterial peptides in stimulated human granulocytes. Eur J Biochem 2002 269:512-518.

5. Kennsebrock K, Krumbholz M, Schönermarck U, Back W, Gross WL, Werb Z, Gröne HJ, Brinkmann V, Jenne DE: Netting neutrophils in autoimmune small-vessel vasculitis. Nat Med 2009, 15:623-625.

6. Fuchs TA, Brill A, Duerschmied D, Schatzberg D, Monestier M, Myers DD Jr, Wrobleski SK, Wakefield TW, Hartwig JH, Wagner DD: Extracellular DNA traps promote thrombosis. Proc Natl Acad Sci U S A 2010, 107:15880-15885.

7. Garcia-Romo GS, Caielli S, Vega B, Connolly J, Allantaz F, Xu Z, Punaro M, Baisch J, Guiducci C, Coffman RL, Barrat FJ, Banchereau J, Pascual V: Netting neutrophils are major inducers of type I IFN production in pediatric systemic lupus erythematosus. Sci Transi Med 2011, 3:73ra20.

8. Lande R, Ganguly D, Facchinetti V, Frasca L, Conrad C, Gregorio J, Meller S, Chamilos G, Sebasigari R, Riccieri V, Bassett R, Amuro H, Fukuhara S, Ito T, Liu YH, Gilliet M: Neutrophils activate plasmacytoid dendritic cells by releasing self-DNA-peptide complexes in system lupus erythematosus. Sci Transi Med 2011, 3:73ra19. 
9. Villanueva E, Yalavarthi S, Berthier CC, Hodgin JB, Khandpur R, Lin AM, Rubin CJ, Zhao W, Olsen SH, Klinker M, Shealy D, Denny MF, Plumas J, Chaperot L, Kretzler M, Bruce AT, Kaplan MJ: Netting neutrophils induce endothelial damage, infiltrate tissues, and expose immunostimulatory molecules in systemic lupus erythematosus. J Immunol 2011, 187:538-552. doi:10.1186/ar3477

Cite this article as: Pisetsky DS: Pus: the Rodney Dangerfield of

immunology. Arthritis Research \& Therapy 2011, 13:131. 